\title{
Towards objectivity in Ostracoda species definition
}

\author{
Alan Lord ${ }^{*}$ \\ Senckenberg Forschungsinstitut und Naturmuseum Frankfurt, Senckenberganlage 25, D-60325 Frankfurt-am-Main, Germany
}

Received: 8 November 2019 / Accepted: 2 July 2020

\begin{abstract}
The problem of consistent identification of unornamented fossil ostracod taxa, especially species, is reviewed in an historical context. The solution lies in modern imaging and image storage and handling technologies combined with a careful but pragmatic (heuristic) approach to identification and taxonomy.
\end{abstract}

Keywords: taxonomy / species / imaging

Résumé - Vers l'objectivité dans la définition des espèces d'ostracodes. On examine, dans son contexte historique, le problème de l'identification cohérente des ostracodes non ornementés. La solution réside dans l'utilisation des techniques modernes de digitalisation d'images et leur traitement, et d'une approche prudente et pragmatique de l'identification et de la taxonomie.

Mots clés : taxonomie / espèces / images

\section{Introduction}

A common remark to ostracod specialists even from fellow palaeontologists' is "Oh, ostracods, little beans!" with the implication that they are essentially unidentifiable and not very useful. While it is true that ostracods are not usually as abundant as foraminifera in marine sediments and are extremely difficult to identify in thin-section, nonetheless, the importance of the group for palaeoenvironmental analysis and biostratigraphy especially of non-marine sequences is well-established (e.g. chapters in Holmes and Chivas, 2002; Park and Smith, 2003; Horne, 2002; Whittaker and Hart, 2009). Living ostracods occur in all aquatic environments from the deep ocean to temporary pools and ground water, their geological record and evolutionary history is long, rich and varied from at least Ordovician to Recent (Oakley et al., 2012; Siveter et al., 2014), and their low-magnesium calcite shells record chemical and isotopic data from the host water (chapters in Holmes and Chivas, 2002; Park and Smith, 2003). Many ostracods have distinctive external ornament and complex internal structures as keys to identification (see Horne et al., 2002), however, in the fossil record there are many taxa that lack external surface ornament, where internal features when observable are simple, and there is only three-dimensional shape to work with. Even with unornamented "beans" it is important to understand that beginners with ostracods can

\footnotetext{
*Corresponding author: alan.lord@senckenberg.de
}

quickly learn how to orientate them: as an introductory student exercise the author gave classes a monospecific assemblage of the smooth Early Jurassic Matacopina species Ogmoconchella aspinata (Drexler) and equipped with very basic knowledge of the animals mode of life within an hour students could orientate the specimens, work out left valve $>$ right valve overlap, and reach the conclusion that the collection of adult and juvenile carapaces and valves probably represents a single species. However, despite this promising start there are fundamental problems with logical and consistent identification of unornamented extinct ostracod taxa, much of which results from poor original material, poor description and/or illustration and subsequent taxonomic adjustments.

Meisch et al. (2019) estimate that there are 2330 "subjective" species of extant non-marine ostracods assigned to 270 genera. Meisch and colleagues use the word "subjective" advisedly as the 2330 named/described species were defined at different times by many different workers and most have not been validated via genetic characterization. The number of living marine and brackish water ostracod species is currently being evaluated via the WoRMS database (World Register of Marine Species) (Simone Brandão, personal communication, 9 July 2019), but in 2000 an estimated figure was 9500 living species and 15500 fossil marine and brackish water species (Koen Martens, OSTRACON, 28 March 2000). Horne et al. (2002) give an estimate of 33000 living and fossil species. These figures are certainly underestimates, as Rodriguez-Lazaro and Ruiz-Muñoz (2012, p. 1) comment "Only about half of the estimated 20000 living species have 
been described formally, the majority from marine and transitional waters".

\section{The problem}

With living ostracods anatomical features of body parts and appendages, including hemipenes, and genetic data together with carapace characteristics are available to aid species recognition. Only exceptionally are soft body parts preserved in the fossil record, as in the very special case of the Silurian Herefordshire Lagerstätte, UK (e.g. Siveter et al., 2012). Thus, of three potential approaches to taxonomy, viz. genetics, appendages, calcified carapace, only the latter is usually available to palaeontologists. In the background is another problem: what is a species? The old idea of a species representing a unique interbreeding group is now very oldfashioned and there is no clear agreement on how to define a biological species, it depends what you mean and where you are coming from. Martens et al. (1998) in discussing ostracod species with mixed reproduction, sexual and asexual, cite Mayden (1997) who listed 25 different species concepts (Martens et al., 1998, Box 11.2). More recently Pante et al. (2015), discussing problems of species recognition and connectivity in living marine organisms, comment (p.527) "described taxa are not facts, but testable hypotheses about the structure of biodiversity. This is true not only for higher taxonomic ranks, generally considered as arbitrary ranks, but also for the species rank, which is the only taxonomic category for which a "biological reality" is recognized by most scientists". Unlike Pante et al. (2015), the palaeontologist also has the time dimension to consider when defining a species in a phylogenetic context, where the species diagnosis is of critical importance. From the palaeontological point-of-view we are simply dealing with "morphospecies" and individual judgement and experience come into play in assessing the variation in morphocharacters permissable in a single (fossil) species. With fossil ostracods it is usually possible to recognise juveniles from adults and often adult males and females from carapace characteristics, but the specimens occur in death assemblages that represent varying distance from the original living population of a species. Why is this important? In simple terms the species is the basic building block for applications ranging from biostratigraphy to environmental interpretation and monitoring to reconstruction of evolutionary processes and patterns through time, and is therefore of fundamental importance.

Key for identification of fossil species are carapace features, i.e.:

- A. External: 1. Three-dimensional shape in dorsal, ventral, left-lateral, right-lateral, anterior and posterior views. 2. Valve overlap and over-reach. 3. Surface morphology including ocular structures, subcentral tubercles or depressions, lobation, contact margin features, caudal process. 4. Surface ornament. 5. Normal pore canals. 6. Marginal rims and spines. 7. Sexual dimorphism features. 8. Juvenile moult stages $c f$. adults.

- B. Internal: 1. Shape of outer margin viewed internally especially in relation to A.1 and A2. 2. Relationship of dorsal margin to free margins. 3. Nature of dorsal hinge structures or contact groove in larger valve. 4. Nature of adductor, frontal, mandibular and other muscle scars. 5. Nature of marginal zone: shape, width, vestibulae, marginal pore canals. 6. Internal morphology reflecting external surface morphology (A.3). 7. Internal nature of normal pore canals. 8. Sexual dimorphism features (A.7). 9. Juvenile moult stages $c f$. adults (A.8).

At first sight numerous criteria from the calcified carapace are thus available for species definition and recognition, however, not all are routinely available, especially with fossil material. Many Palaeozoic and early Mesozoic taxa have relatively simple internal structures and muscle scars are only occasionally preserved and visible.

\section{Visualisation and comparison}

As the list below will demonstrate, in a few decades palaeontologists have moved from free-hand or camera-lucida drawings and simple light photographs of fossils to technologies that not only image but also allow precise comparison of shapes and surfaces with the ability to apply a confidence factor to the comparisons. Of course, with fossil material lacking soft parts and genetic information, close comparison of shells does not necessarily give evidence of a biological closeness or relationship.

2D: 1. Line drawings - some are very good (e.g. Müller, 1894; Sars, 1922-1928; Benson, 1964; Maddocks, 1966) but many others are a less helpful guide to reliable species identification. It is worth commenting that the preparation of line drawings helps the "artist" to understand the structures and therefore to highlight key elements in the drawing. 2. Photographic and digital images via light microscopy (LM) and scanning electron microscopy (SEM)-LM, until the advent of modern digital imaging with computer graphics few publications rivaled the transmitted and reflected light figures of Triebel (e.g. 1941); SEM, particularly important for ostracods where all important carapace taxonomic features except for marginal pore canals for visible on the shell surface. 3. Carapace outline geometry - Herrig (1979a) applied a geometrical approach to analyzing the lateral outlines of Lower Jurassic Bairdia species, and similarly Forel and Grădinaru (2018) measured the relative lengths and angles of dorsal margin elements in Triassic species of Acratia, Bairdia, Kempfina and Paracypris to provide objectivity in describing these smooth taxa; the software package "MORPHOMATICA" facilitates comparison of valve outlines (e.g. Danielopol et al., 2014; Gitter et al., 2015), further developed as Geometric Morphometrics by Wrozyna et al. (2016), and $c f$. image analysis of sediment grains (e.g. Klosa, 1991).

3D: 1. Line drawings of serial sections aimed at a $3 \mathrm{D}$ impression (e.g. Lethiers, 1972, Fig. 4). 2. Stereopairsstereopair visualisation of photographic images followed quickly after the early development of photography, but in the context of micropalaeontology the technique was rejuvenated by the ease with which stereo images can be made in the SEM (Sylvester-Bradley, 1973), and stereo effect can also be achieved by red/green false colouring available in modern SEMs (e.g. Swanson, 2012). 3. Computer graphic reconstruction of ground or sliced images (Herefordshire LagerstätteSutton et al., 2001, 2014; Siveter et al., 2012). 


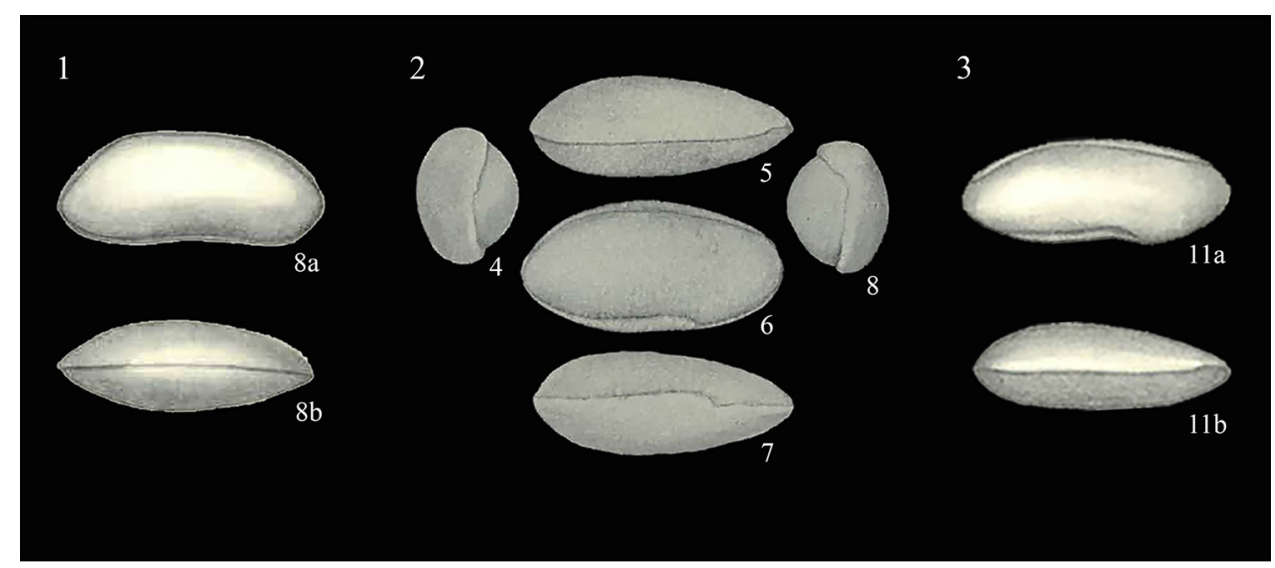

Fig. 1. Original illustrations of Bairdiacypris and Fabalicypris.

1. Bairdiacypris deloi Bradfield (1935).

Fig. 1. Plate 7, figs. 8a and 8b of Bradfield: type species of genus, Holotype; Locality 13 of Bradfield, Ardmore, Ardmore Basin, Oklahoma, USA; Hoxbar Formation, Pennsylvanian, Upper Carboniferous.

Fig. 8a: carapace right lateral view; 8b: carapace dorsal view. Dimensions: (text, p. 93) L=1.32, H=0.54, W=0.45; (figure caption, p. 160, magnification factor $\mathrm{x} 27$ ) $\mathrm{L}=1.26, \mathrm{H}=0.52, \mathrm{~W}=0.41$.

2. Fabalicypris wileyensis Cooper (1946).

Plate 6, figs. 4-8 of Cooper: type species of genus, Holotype; Locality 13 of Cooper, Illinois, USA; Wiley "zone", Cherokee Group, Pennsylvanian, Upper Carboniferous.

Fig. 4: carapace posterior view; 5: carapace dorsal view; 6: carapace right lateral view; 7: carapace ventral view; 8: carapace anterior view. Dimensions: (text, p. 61) $\mathrm{L}=1.02, \mathrm{H}=0.53, \mathrm{~W}=0.42$; (figure caption, p. 138, magnification factor $\times 30$ ) $\mathrm{L}=1.06, \mathrm{H}=0.53, \mathrm{~W}=0.42$.

3. Fabalicypris warthini (Bradfield, 1935).

Plate 5, figs. 11a and 11b of Bradfield: presumed Holotype; original x 27 slightly enlarged here; Locality 98 of Bradfield, Deese, Ardmore Basin, Oklahoma, USA; Deese Formation, Pennsylvanian, Upper Carboniferous.

Fig. 11a: carapace right lateral view; 11b: carapace dorsal view. Dimensions (text, p. 83) L=1.07, H=0.41, W=0.34; (figure caption, p. 156, magnification factor $\mathrm{x} 27) \mathrm{L}=1.04, \mathrm{H}=0.41, \mathrm{~W}=0.33$. Abbreviations: $\mathrm{L}=$ length, $\mathrm{H}=$ height, $\mathrm{W}=$ width. Dimensions in mm.

The future: Computed tomography and magnetic resonance imaging, see Ziegler et al. (2018) on Mollusca, combined with publicly available databases of images of type specimens.

\section{Case study: Bairdiacypris Bradfield (1935) and Fabalicypris Cooper (1946)}

Bairdiacypris was described from the Pennsylvanian (Upper Carboniferous) of Oklahoma by Bradfield (1935) established on the new species B. deloi (Fig. 1, fig. 1; Fig. 2, figs. 1a and 1b). Later, Cooper (1946) erected the new genus Fabalicypris based on his new species F. wileyensis (Fig. 1, fig. 2) from the Upper Carboniferous of Illinois. Subsequently, Sohn (1960) reviewed these taxa and placed the species Bairdia warthini Bradfield (1935) into Fabalicypris (Fig. 1, fig. 3). The genera are similar only in as much as both are elongate with a concave ventral margin, are unornamented and lack strong surface morphological features, and both have left valve > right valve overlap; they differ in the geometry of the lateral valve outlines and nature of valve overlap ventrally. Internal features were not mentioned in either case in the original descriptions.

Kozur (1971) placed two new Triassic species in Bairdiacypris, citing Belousova (1965) as a source. The first use of the genus Bairdiacypris in the Jurassic was by Donze (1966 - who cites Elmi and Mouterde (1965) but without giving the reference) for B. sartriensis Donze (1966) from the
Hettangian of Ardèche, France and was followed in this generic designation by Lord (1971) for specimens from the Hettangian of Yorkshire, UK, in both cases without meaningful discussion of the use of a Palaeozoic genus for Mesozoic species. Similarly Donze (1966) recognised a new species as Fabalicypris praelonga without comment. Drexler (1958) placed Lower Jurassic (Hettangian) species in the Palaeozoic genera Healdia Roundy (1926) and Krausella Ulrich (1894). These appear to be the first applications of names of Palaeozoic genera to post-Palaeozoic species.

Herrig (1979a) describing material from the Lower Jurassic of eastern Germany placed new species in both Bairdiacypris and Fabalicypris, and although the new taxa were thoroughly described and figured there was again no discussion of the generic assignments. This pattern was followed by later workers, for examples, Harloff (1993) carefully describes and figures one species each of Bairdiacypris and Fabalicypris but without comment on the genera, and similarly Beher (2004) describes and figures seven species of Bairdiacypris and five of Fabalicypris, in both cases from the Lower Jurassic of SW Germany. The use of Bairdiacypris for Lower Jurassic species is now well-established.

\section{Discussion}

Personal experience and anecdotal information indicate that few workers now visit collections to compare type material, despite enlightened funding via programmes such as 


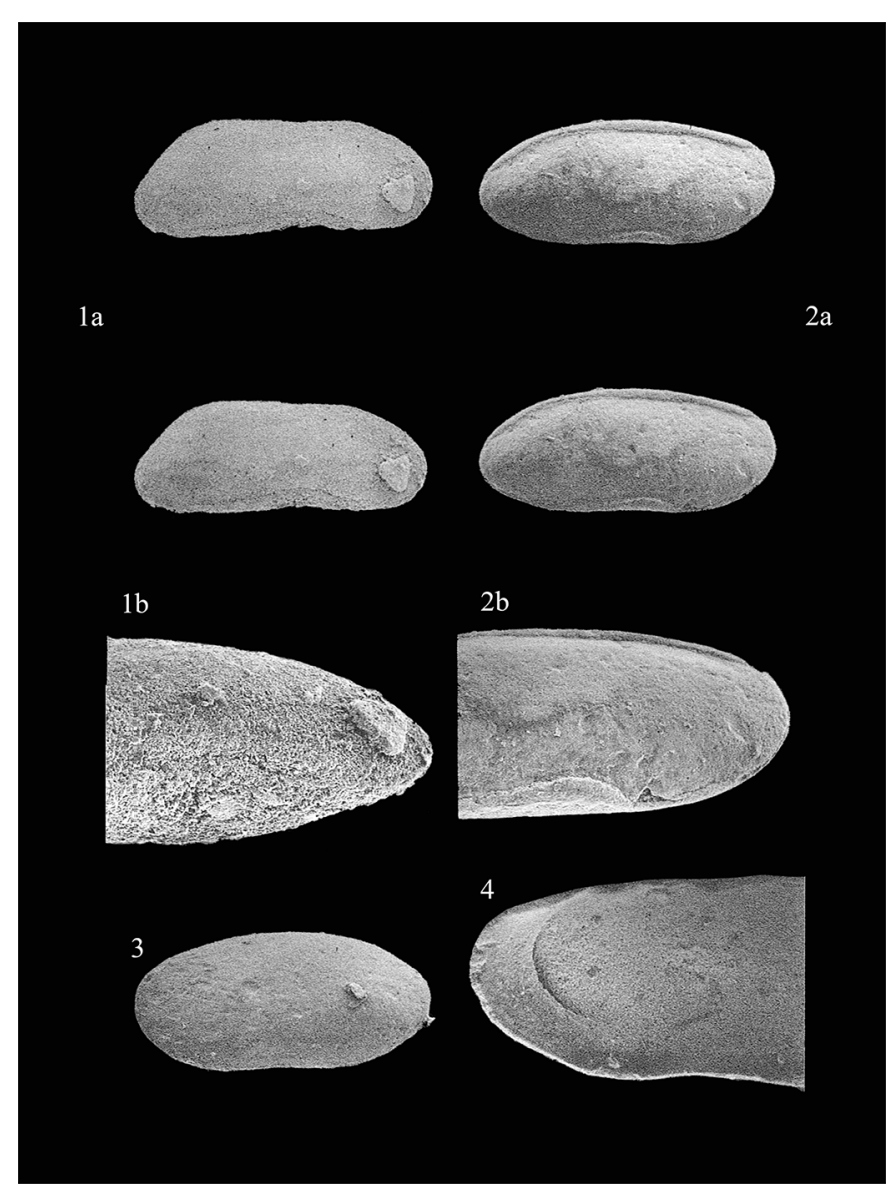

Fig. 2. 1a, b. Bairdiacypris deloi Bradfield (1935).

USNM 307374 Carapace (converted to fluorite); topotype of type species of Bairdiacypris Bradfield (1935); Locality 13 of Bradfield, south edge Ardmore, Carter County, Oklahoma, USA (Sohn, 1960, p. 57).

1a. Carapace right lateral view, stereopair; $\mathrm{L}=0.66 \mathrm{~mm}$, $\mathrm{H}=0.26 \mathrm{~mm}$. 1b. Carapace antero-ventral detail; width $0.48 \mathrm{~mm}$.

2a, b. Fabalicypris warthini (Bradfield, 1935) USNM 307375 Carapace; Locality Carter County, Oklahoma, USA (Sohn, 1960, p. 64).

2a. Carapace right lateral view, stereopair; $\mathrm{L}=0.98 \mathrm{~mm}$, $\mathrm{H}=0.42 \mathrm{~mm}$; note strong $\mathrm{LV}$ dorsal margin overhang and LV ventral margin extension or "step".

2b. Carapace anterior to show ventral margin "step".

3. Fabalicypris warthini (Bradfield, 1935) USNM 307376 Carapace, left lateral view; $\mathrm{L}=0.92 \mathrm{~mm}, \mathrm{H}=0.42 \mathrm{~mm}$; Locality as Figure 2 .

4. Fabalicypris warthini (Bradfield, 1935) USNM 307377 RV, internal lateral view of anterior to show width of marginal zone and vestibule; $\mathrm{H}=0.39 \mathrm{~mm}$; Locality as Figure 2 .

SYNTHESYS, or request loan or comparative material, or SEM images from colleagues, and are therefore relying on published images. In this respect the demise of the pioneering A Stereo-Atlas of Ostracod Shells is particularly unfortunate but subscription income no longer supported its publication.

The example of Bairdiacypris and Fabalicypris demonstrates the difficulties involved with taxonomy based on fossil material. There are numerous cases. It seems unlikely that "Bythocypris" from the Jurassic is biologically close or related to the living genus Bythocypris Brady (1880), despite similar carapace characteristics, because of the $190 \mathrm{Ma}+$ time interval involved; some examples: Lower Jurassic: south-west Germany (Drexler, 1958), eastern Germany (Herrig, 1979b), south west Germany (Harloff, 1993), south Germany-western Austria (Harloff and Jäger, 1994), south Germany-north Switzerland (Beher, 2004), Hungary (Monostori, 2008), Argentina (Ballent, 1987); Middle Jurassic: southern Tunisia (Mette, 1995), India (Khosla et al., 2009), Argentina (Ballent, 1991). A parallel but different example concerns the genus Xestoleberis Sars (1866), described from living material and with a fossil record from the mid Cretaceous (c. $95 \mathrm{Ma}$ ) (Slipper 2009a, p. 353), with an unornamented "bean" carapace but with a characteristic antero-dorsal scar called the Xestoleberis-spot present in both living and fossil species, which provides a more convincing case for genus longevity.

In principle there is no reason why a genus-level taxon should not have survived from the Palaeozoic, through the catastrophic Permian extinction event, and be represented in the Mesozoic by successor species. Above it is argued here that the long time intervals involved militate against this happening in nature, but the real problem, discussed above, is reliable comparative taxonomy.

Most workers looking at a fossil assemblage consciously or unconsciously refer to literature relating to the relevant timeframe for taxonomic precedent or inspiration and use taxa previously recognized, which is a comfortable and comforting procedure but may not advance science. Isobythocypris Apostolescu (1959) described from Early Jurassic sediments of the Paris Basin is a reasonably consistently recognised genus that appears to be restricted to the late Triassic-Early Jurassic, but what are its ancestors and descendents? Few workers now look at samples vertically (to use a wine tasting analogy), i.e. looking at genera and their included species over extended timescales, yet this is essential to understand evolutionary patterns and hopefully process - what are "real" clades and can we ever get close to them with most fossil material?

Two further examples of problematic genus names follow, in the first case a Palaeozoic taxon applied to post-Palaeozoic material, and in the second a Mesozoic taxon confusingly similar to other Palaeozoic and Mesozoic genera:

1 Krausella Ulrich (1894) (Lower Silurian, Minnesota), a name used by both Drexler (1958) and Apostolescu (1959) but no longer recognized in the Lower Jurassic.

2 Pontocyprella Mandelstam, 1955 (in Luebimova 1955) (type species Bairdia harrisiana Jones; Cretaceous). Confusingly the genus is attributed to Mandelstam in the publication but the only species actually described is P. aureola Luebimova (1955) from the Callovian-Oxfordian; some Pontocyprella are very similar to Palaeozoic Fabalicypris, e.g. P. harrisiana figured in Slipper (2009b, Pl.1, fig. 15) and to Isobythocypris.

Taking a broader perspective, "taxonomic harmonisation" is a term recently applied to a practical approach to consistent species identification, particularly in the context of ostracod distributional databases applied to climate reconstruction (Horne et al., 2011a, b), especially in circumstances where it may be difficult to conclusively demonstrate conspecificity 
between specimens from different regions. Danielopol et al. (2015) develop this idea, introducing the term "consensus species" and using the expression "a heuristic solution". The word "heuristic" has two meanings (Oxford English Dictionary): 1. enabling a person to discover or learn something for themselves, and 2. (IT) reaching a solution by trial and error or rules that are loosely defined. Definition 2. is applicable but I am also attracted by Definition 1. In contrast, Wikipedia defines "heueristic" as: "any approach to problem solving or selfdiscovery that employs a practical method that is not guaranteed to be optimal, perfect or rational, but instead sufficient for reaching an immediate goal". For the palaeontologist, the solution to achievable consistency in ostracod species definition lies in modern imaging and image storage and handling technologies combined with a careful but pragmatic (heuristic) approach to identification and taxonomy in a time context.

\section{Conclusions}

The problems of consistently identifying fossil species, in this case ostracods, is discussed in terms of them being morphospecies which may or may not have had biological reality. It is worth reminding ourselves of the comment of Pante et al. (2015, p. 527) discussing living species: "described taxa are not facts, but testable hypotheses".

In a generation we have moved from subjective drawings and usually poor quality light micrograph illustrations of living and fossil ostracod species to the vast potential of digital imaging, analysis, manipulation and storage. There is therefore no excuse for poor or minimal illustration of any figured species, but especially those described as new. Publications with species lists but no illustrations are of very limited value. Image capture, storage, manipulation and comparison technologies improve at an ever increasing rate and provide the support for a careful, consistent but pragmatic approach to species description and identification, in a time context, and thereby to enhanced applications.

Acknowledgements. The late I.G. Sohn (U.S. Geological Survey) is gratefully acknowledged for facilitating the loan of U.S. National Museum material. Claudia Franz and Gunnar Riedel (Frankfurt) are thanked for technical assistance. I am grateful to Dan Danielopol for stimulating me to think about these matters and to Cristina Cabral, Marie-Béatrice Forel and Simone Nunes Brandão for helpful discussion. David Horne read a draft version and provided many sage comments. Helpful reviews by Dan Danielopol and David Siveter are gratefully acknowledged. Images from Bradfield (1935) are reproduced with kind permission of the Paleontological Research Institution, Ithaca, USA.

\section{References}

Apostolescu V. 1959. Ostracodes du Lias du Basin de Paris. Revue de l'Institut Français du Pétroles et Annales des Conbustibles Liquides 14: 795-826.

Ballent SC. 1987. Bioestratigrafia y edad de las microfaunas del Jurasico Inferior de Argentina. IV Congreso Latinamericano de Paleontologia, Bolivia 1: 331-342.

Ballent SC. 1991. Ostracodos del Jurasico Medio (Limite AalenianoBayociano) en la Provincia del Neuquen, centro-oeste de Argentina. Revista Española de Micropaleontologia 23(3): 21-56.
Beher E. 2004. Ostracodenfauna und Biostratigraphie im OberSinemurium von Süddeutschland und der Nordschweiz. Stuttgarter Beiträge zur Naturkunde B 349: 1-171.

Belousova ZD. 1965. Tip Arthropoda, Klass Crustacea, Podclass Ostracoda. Trudy Paleontologicheskogo Instituta, Akademia Nauk, SSSR 108: 254-265.

Benson RH. 1964. Recent cytheracean ostracodes from the McMurdo Sound and the Ross Sea, Antarctica. University of Kansas Paleontological Contributions Article 6: 1-36.

Bradfield HH. 1935. Pennsylvanian Ostracoda of the Ardmore Basin, Oklahoma. Bulletins of American Paleontology 22(73): 1-173.

Brady GS. 1880. Report on the Ostracoda dredged by H.M.S Challenger during the years 1873-1876. Report on the scientific results of the voyage of H.M.S. Challenger during the years 1873 1876. Zoology 1(3): 1-184.

Cooper CL. 1946. Pennsylvanian Ostracodes of Illinois. Bulletin of the Illinois Geological Survey 70: 1-177.

Danielopol DL, Pinto RL, Gross M, Pereira J da S, Riedl N. 2014. On the evolutionary biology of Elpidium ostracods (Limnocytheridae, Timiriaseviinae): a proposal for pluridisciplinary studies. Geo-EcoMarina 20: 87-129.

Danielopol DL, Namiotko T, Grafenstein U von, Fuhrmann R, Decrouy L, Gross M, et al. 2015. The implementation of taxonomic harmonisation for Candoninae (Ostracoda, Cypridoidea): a heueristic solution for Fabaeformiscandona tricicatricosa (Diebel and Pietrzeniuk). Geo-Eco-Marina 21: 111-158.

Donze P. 1966. Ostracodes de 1'Hettangien entre Aubenas et Privas (Ardèche). Travaux des Laboratoires de Géologie de la Faculte des Sciences de Lyon NS, 13: 121-139.

Drexler E. 1958. Foraminiferen und Ostracoden aus dem Lias $\alpha$ von Siebeldingen/Pfalz. Geologisches Jahrbuch 75: 475-554.

Elmi S, Mouterde R. 1965. Cited by Donze (1966) without details.

Forel M-B, Grădinaru E. 2018. First report of ostracods (Crustacea) associated with Bithynian (Anisian, Middle Triassic) Tubiphytesmicrobial reef in the North Dobrogean Orogen (Romania). Papers in Palaeontology 1-34. https://doi.org/10.1002/spp2.1103.

Gitter F, Gross M, Piller WE. 2015. Sub-decadal resolution in sediments of Late Miocene Lake Pannon reveals speciation of Cyprideis (Crustacea, Ostracoda). PloS ONE 10(4): e0109360. https://doi.org/10.1371/journal.pone.0109360.

Harloff J. 1993. Ostracoden des Unter-Pliensbachiums in BadenWürttemberg. Stuttgarter Beiträge zur Naturkunde B 191: 1-214.

Harloff J, Jäger R. 1994. Ostracoden aus dem Lias der Kalkalpen Bayerns und Nordtirols. Stuttgarter Beiträge zur Naturkunde B 205: 1-63.

Herrig E. 1979a. Ostrakoden aus dem Lias von Thüringen: Die Gattung Bairdia (Teil II), Fabalicypris und Bairdiacypris. Zeitschrift für Geologische Wissenschaften 7: 763-782.

Herrig E. 1979b. Weitere glattschalige Ostrakoden aus dem Lias von Thüringen. Zeitschrift für Geologische Wissenschaften 7: 13431361.

Holmes JA, Chivas AR, eds. 2002. The Ostracoda. Applications in Quaternary Research. Geophysical Monograph 131: viii + 1-313. American Geophysical Union.

Horne DJ. 2002. Ostracod biostratigraphy and palaeoecology of the Purbeck Limestone Group in Southern England. Special Papers in Palaeontology 68: 1-18.

Horne DJ, Cohen A, Martens K. 2002. In: Holmes JA, Chivas AR, eds. Taxonomy, morphology and biology of quaternary and living Ostracoda, pp. 5-36.

Horne DJ, Bunbury J, Whittaker JE. 2011a. Taxonomic harmonisation and calibration of nonmarine ostracods for palaeoclimate applications: the case of Candona acutula Delorme, 1967. Joannea Geologie und Paläontologie 11: 76-79. 
Horne DJ, Jocque M, Brendonck L, Martens K. 2011b. On Potamocypris compressa (Crustacea, Ostracoda) from temporary rock pools in Utah, USA, with notes on the taxonomic harmonisation of North American and European ostracod faunas. Zootaxa 2793: 35-46.

Khosla SC, Jakhar SR, Kumari M. 2009. Atlas of the Middle Jurasssic Ostracods from Western India. Lucknow: Palaeontological Society of India, 167 p.

Klosa D. 1991. Kornformbestimmung mit Hilfe moderner Bildanalysemethoden. Geologisches Jahrbuch A 126: 235-255.

Kozur H. 1971. Die Bairdiacea der Trias. Teil III: Einige neue Arten triassischer Bairdiacea und Bemerkungen zur Herkunft der Macrocypridae (Cypridacea). Geologisch-Paläontologische Mitteilungen Innsbruck 1(6): 1-18.

Lethiers F. 1972. Ostracodes famenniens dan l'Ouest du Basin de Dinant (Ardenne). Annales de la Société Géologique du Nord XCII: $155-169$.

Lord A. 1971. Revision of some Lower Lias Ostracoda from Yorkshire. Palaeontology 14: 642-665.

Luebimova PS. 1955. Ostrakody Mezozoyskikh otlozheniy srednego povozhya i obshchego syrta. (Ostracods of Mesozoic deposits in the Volga-Ural region). Trudy VNIGRI, New series, 84: 3-189.

Maddocks RF. 1966. Distribution patterns of living and subfossil podocopid ostracodes in the Nosy Bé area, northern Madagascar. University of Kansas Paleontological Contributions, Paper 12, 172.

Martens K, Rossetti G, Baltanás A. 1998. Reproductive modes and taxonomy. In: Martens $\mathrm{K}$, ed. Sex and parthenogenesis: evolutionary ecology of reproductive modes in non-marine ostracods, pp. 197-214. Leiden: Backhuys.

Mayden RL. 1997. A hierarchy of species concepts: the denouement in the saga of the species problem. In: Claridge MF, Dawah HA, Wilson MR, eds. Species, the units of diversity, pp.381-424. Chapman \& Hall.

Meisch C, Smith RJ, Martens K. 2019. A subjective global checklist of the extant non-marine Ostracoda (Crustacea). European Journal of Taxonomy 492: 1-135. https://doi.org/10.5852/ejt.2019.492.

Mette W. 1995. Ostracods from the Middle Jurassic of southern Tunisia. Beringeria 16: 259-348.

Monostori M. 2008. Comparative study of the Pliensbachian and Toarcian ostracods in the Gerecse and Mecsek Mountains, Hungary. In: Galácz A, ed. 125th Anniversary of the Department of Palaeontology at Budapest. Hantkeniana 6: 17-31.

Müller GW. 1894. Die Ostracoden des Golfes von Neapel und der angrenzenden Meeres-Abschnitte. Fauna und Flora des Golfes von Neapel und der angrenzenden Meeres-Abschnitte. Herausgegeben von der Zoologischen Station zu Neapel 21: 1-404.

Oakley TH, Wolfe JM, Lindgren AR, Zaharoff AK. 2012. Phylotranscriptomics to bring the Understudied into the Fold: Monophyletic Ostracoda, Fossil Placement, and Pancrustacean Phylogeny. Molecular Biology and Evolution 30: 215-133. https:// doi.org/10.1093/molbev/mss216.

Pante E, et al. 2015. Species are hypotheses: avoid connectivity assessments based on pillars of sand. Molecular Ecology 24: 525544.

Park LE, Smith AJ, eds. 2003. Bridging the Gap. Trends in the Ostracode and Biological Sciences. Paleontological Society Papers 9: xviii + 1-290.
Rodriguez-Lazaro J, Ruiz-Muñoz F. 2012. A General Introduction to Ostracods: Morphology, Distribution, Fossil Record and Applications. In: Horne DJ, Holmes JA, Rodriguez-Lazaro J, Viehberg FA, eds. Ostracoda as Proxies for Quaternary Climate Change, pp. 1-14. Developments in Quaternary Science, 17. Amsterdam: Elsevier.

Roundy PV. 1926. Mississippian formations of San Saba County, Texas. Part 2: The Micro-fauna. United States Geological Survey Professional Paper 146: 5-17.

Sars GO. 1866. Oversigt af Norges marine ostracoder. Forhandlinger i Videnskabs-selskebet i Christiania 1865: 1-130.

Sars GO. 1922-1928. An Account of the Crustacea of Norway, IX Ostracoda. xii $+1-227$. Norway: Bergen Museum.

Siveter DJ, Briggs DEG, Siveter DJ, Sutton MD, Joomun SC. 2012. A Silurian myodocope with preserved soft-parts: cautioning the interpretation of the shell-based ostracod record. Proceedings of the Royal Society, B 280: 20122664. https://doi.org/10.1098/ rspb.2012.2664.

Siveter DJ, Tanaka G, Farrell ÚC, Martin MJ, Siveter DJ, Briggs DEG. 2014. Exceptionally Preserved 450-Million-Year-Old Ordovician Ostracods with Brood Care. Current Biology 24: 801-806.

Sohn IG. 1960. Paleozoic Species of Bairdia and Related Genera. United States. Geological Survey Professional Paper 330-A: iii + $1-105$.

Slipper IJ. 2009a. Upper Cretaceous. In: Whittaker JE, Hart MB, eds. Ostracods in British Stratigraphy, pp.345-372. The Micropalaeontological Society, Special Publications. London: The Geological Society.

Slipper IJ. 2009b. Marine Lower Cretaceous. In: Whittaker JE, Hart MB, eds. Ostracods in British Stratigraphy, pp.309-343. The Micropalaeontological Society, Special Publications. London: The Geological Society.

Sutton MD, Briggs DEG, Siveter DJ, Siveter DJ. 2001. Methodologies for the visualisation and reconstruction of three-dimensional fossils from the Silurian Herefordshire Lagerstätte. Palaeontologia Electronica 4(1/1): 17.

Sutton MD, Rahman IA, Garwood RJ. 2014. Techniques for virtual palaeontology. New York: Wiley-Blackwell, 208 p.

Swanson KM. 2012. Bugs in the Ocean. Australia: CSIRO Publishing, Collingwood VIC 3066, 95 p.

Sylvester-Bradley PC. 1973. The new Palaeontography. A StereoAtlas of Ostracod Shells 1(1): 1-4.

Triebel E. 1941. Zur Morphologie und Ökologie der fossilen Ostracoden.mit Beschreibung einiger neuer Gattungen und Arten. Senckenbergiana 23: 294-400.

Ulrich EO. 1894. The Lower Silurian Ostracoda of Minnesota. The Geology of Minnesota (Final Report, Chapter 7) 3(2): 629-693.

Whittaker JE, Hart MB, eds. 2009. Ostracods in British Stratigraphy. The Micropalaeontological Society, Special Publications. London: The Geological Society, $485 \mathrm{p}$.

Wrozyna C, Neubauer TA, Meyer J, Piller WE. 2016. Shape variation in Neotropical Cytheridella (Ostracoda) using semilandmarksbased Geometric Morphometrics: A methodological approach and possible biogeographical implications. PLoS ONE 11(12): 1-16. https://doi.org/10.1371/journal.pone.0168438.

Ziegler A, Bock C, Ketten DR, Mair RW, Mueller S, Nagelmann N, et al. 2018. Digital three-dimensional imaging techniques provide new analytical pathways for malacological research. American Malacological Bulletin 36: 248-273.

Cite this article as: Lord A. 2020. Towards objectivity in Ostracoda species definition, BSGF - Earth Sciences Bulletin 191: 27. 